\title{
MIGRĀCIJAS IZPĒTES PIEREDZE PADOMJU LATVIJĀ
}

\section{Pārsla Eglīte}

Anotācija. Raksts sniedz atskatu uz migrācijas īpatnībām un tās izpētes iespējām padomju varas gados, kad Latvija piedzīvoja masveida imigrāciju galvenokārt no Krievijas un Baltkrievijas tuvējiem apgabaliem. Tā izraisīja iedzīvotāju vecumsastāva izkropḷojumus gan izcelsmes, gan jaunajās mītnes vietās, kas sekmēja vienās drīzāku, otrās vē̄āk sekojošu pārlieku novecošanos. Lai noklusētu notiekošās kolonizācijas sekas, datu pieejamība par to tika ierobežota, bet sagatavotās publikācijas politiski cenzētas.

Atslēgas vārdi: imigrācija, migrantu vecumsastāvs, migrācijas demogrāfiskās sekas, politiskā cenzūra.

Apzīmētājs padomju attiecas gan uz politisko iekārtu laikposmā no 2. pasaules kara beigām līdz valsts neatkarības atjaunošanai, gan pētāmās parādības norises īpatn̄īām un sekām šais apstākḷ̆os, gan tās pētniecības iespējām un šĩ darba secinājumu uztveri varas pārstāvju vidū.

Pirmajā padomju varas gadā Latvijā - 1940./1941. - skaitliski būtiska migrācija vēl nenotika, ja neņem vērā kādu politisku darboṇu un armijas daḷu ierašanos, par kuru daudzumu ziņu nav. Savukārt 14 tūkstošu vietējo iedzīvotāju izsūtǐšana uz attālākiem PSRS austrumu apvidiem nav īsti uzskatāma par migrāciju, jo pēdējā tiek saprasta kā dz̄ivesvietas maiṇa pēc indivīda paša lēmuma, kaut arī dažādu draudu, ekonomisko vai citu ārējo apstākḷu ietekmēe (Multilingual ...1982, 92).

Tūlīt pēc karadarbības izbeigšanās Latvijas teritorijā sākās gan demobilizēto padomju armijas karavīru un īpaši virsnieku izmitināšana Rīgā un citās pilsētās, gan civiliedzīvotāju masveida ierašanās no karadarbībā un vācu okupācijas darbībā vairāk izpostītiem kaimiņrepubliku apvidiem. Tie apmetās paši un tika izmitināti ne vien uz rietumiem no padomju varas aizbēgušo Latvijas iedzīvotāju atstātajos mājokḷos, bet arī palikušo dzīvokḷos, izvietojot tajos, it kā pārāk lielā platībā, nelūgtos kaiminuus. Cilvēki to redzēja un bija spiesti pieciest (Okupācijas ... 1999, 349-376). Darba vietās un pakalpojumu iestādēs arvien biežāk saziņa notika vienīgi krievu valodā.

Pret notiekošo rusifikāciju un nesamērīgo mašīnbūves attīstību, lai gan tai nepieciešamo resursu Latvijā nebija, iestājās daḷa vadošos amatos nokḷuvušo latviešu, piemēram, E. Berklavs, un arī pētnieki. Zinātņu akadēmijas Ekonomikas institūta direktora P. Dzērves 1959. gadā sagatavotajā izpētes programmā "Latvijas PSR tautas saimniecības attīstības perspektīvas" bija uzsvērta darbaspēka bilances saspringtība. Atzîts, ka "turpmākā tādu nozaru un ražotņu attīstīšana, kas balstās uz tādu izejvielu izmantošanu, kas pievestas no tālienes, kurām nav pastāvošu ražošanas jaudu un vietējo darba resursu, no ekonomiskā viedokḷa nav uzskatāma par mērḳtiecīgu (Latvija padomju... 2001, 237 - 238). Š̄is nostādnes pārbaudei īpaši izveidota komisija ar Vissavienības iestāžu pārstāvjiem tās sastāvā atzina programmu par aplamu un tās īstenošanu par spējīgu nodarīt lielu kaitējumu PSRS tautsaimniecības attīstībai kopumā. P. Dzērve tika atbrīvots no amata, tāpat viņa domubiedrs, toreizējais Ministru Padomes priekšsēdētāja vietnieks E. Berklavs un daži citi tā dēvētie nacionālekonomisti. Taču republikas kolonizācija turpinājās. 
1961. gada vasarā tiku pieṇemta darbā minētajā institūtā. Līdz tam tā sastāvā pastāvējušais un manis iecerētais Ekonomiskās ǵeogrāfijas sektors bija tikko pārcelts uz universitāti, tāpēc nonācu Darba resursu sektorā. Viens no darba uzdevumiem bija darba resursu pirmsplāna prognožu izstrāde republikas kārtējam piecgades plānam.

Kā zināms, katra bilance sastāv no divām daḷām: pirmā - paredzamo resursu no dažādiem avotiem pieauguma iespēju aprēķins, otra - šo resursu izlietojuma veidi. Darba resursu bilances pirmajā dậā - darbaspējīgo iedzīvotāju skaits bāzes gadā un plāna periodā no dabiskā pieauguma (darbspējas vecumu sasniegušo skaita no agrāk dzimušām paaudzēm un prognozes periodā mirušo vai pensionējušos skaita starpības) un tolaik par mehānisko dēvētā pieauguma - migrācijas, speckontingenta (armijā dienējošo un ieslodzīto skaita) un teritoriālajām pārmaiṇām (pagastu, apriņ̧̧u robežu maiņu, pilsētu tiesību piešķiršanu u.tml.). Bilances pirmās dą̧as izstrādēs mehāniskā pieauguma vietā rēḳinājāmies tikai ar varbūtējām migrācijas pieauguma pārmaiṇām, jo dienējošo un ieslodzīto skaits bija slepens. Otrajā bilances daḷā paredzamo darbaspējīgo un darba gaitas varbūtēji turpinošo pensionāru skaitu dalīja atbilstoši nodarbinātības veidiem - mācībām, darbu tautsaimniecības dažādās nozarēs vai mājsaimniecībā.

Toreiz pastāvējušajā Valsts plāna komisijas Darba resursu nodaḷā rīkojās citādi. Vispirms vāca visu ministriju paredzêtās prasības pēc darbaspēka un tad meklēja darbaspējīgo papildinājuma iespējas šo prasību kopuma apmierināšanai. Padomju Latvijā, kur arvien lielāka rūpniecības un transporta uzṇēmumu daḷa bija Vissavienības un nevis republikas pakḷautībā, darbaspēka pieprasījuma plāni vienmēr pārsniedza tā paredzamo dabisko pieaugumu. Tādēl visos piecgades plānos PSRS Valsts plāna komisijai tika prasīts migrācijas pieaugums Latvijas PSR augošo plānu izpildei (Latvija padomju ... 2001, 171).

Mūsu darbā grūtības radīja vajadzīgo izejas datu trūkums par iedzīvotāju skaitu, vecumsastāvu un kustību. Pat pēc Staliina nāves (1953. gadā) un viṇa personības kulta nosodījuma Kompartijas XX kongresā 1956. gadā Latvijas CSP izdotajā datu krājumā 1957. gadā par republikas tautsaimniecību tikai 3 nelielas tabulas 2 lappusēs bija veltîtas iedzīvotāju skaitam 1930. un 1935. gadā vecajās robežās, bet 1940. un 1956. jaunajās (bez bijušā Abrenes apriṇķa 5 pagastiem), kā arī dabiskajam pieaugumam atsevišksos gados no 1950. līdz 1955. gadam un sešu lielāko pilsētu iedzìvotāju skaitam (Latvijas PSR ...1957, 7-8). Arī pirmās pēckara tautskaites datu krājumā (Итоги ... 1962) atrodams tikai visu Latvijas iedzīvotāju - vīriešu un sieviešu, pilsētās un laukos - skaits 5 gadu vecumgrupās un šo pašu grupu bez vecuma norādes dalījums pēc dzimtās valodas: latviešu, krievu vai citās. Trūka migrācijas izpētei derīgo datu par dzimšanas un iepriekšējo dzīvesvietu, kā arī dzīvošanas ilgumu pašreizējā vietā.

Kaut cik noderīgi dati bija atrodami vien̄̄gi atklātai publicēšanai aizliegtajā krājumā - tikai dienesta lietošanai (Численность ... 1961; Численность ... 1966). tādiem bija neliela tirāža, visi eksemplāri numurēti un glabājami seifā. Man arī tika piešķirtas tiesības tādus izmantot, bet publikācijās nedrīkstēja būt pat norādes uz tajos atrodamo datu avotu, ne tikai kādi skaitḷi no tiem. Ar tādiem priekšnosacījumiem, sākot ar 1971. gadu, t.i., pēc 1970. gada tautskaites, sāka iznākt arī ikgadējo statistisko datu 
krājums par iedzīvotāju dabisko un mehānisko kustību, kur bija atrodamas ḷoti noderīgas ziṇas - par iebraukušo migrantu izbraukšanas vietām: savienotajām republikām un pat apgabaliem ar lielāko pārcēlušos skaitu (Естественное ... 1972). Tikai 1990. gadā ikgadējais statistikas datu krājums par iedzīvotāju kustību sāka iznākt latviski un bez publicēšanas ierobežojumiem. Bet tad jau imigrācija no grūstošās PSRS un vissavienības iestāžu diktāts beidzās.

60. gados visai pieticīgos publicētos datus papildināja Statistikas pārvaldes uzkrāto pierakstīšanās dzīvesvietā lapiṇu papildapstrāde par 1959.-1965. gadu (Эглите 1967, 6, 10-11). Tas deva iespēju raksturot migrācijas atšķirīgo intensitāti pēc pārcelšanās attāluma un tās izraisīto iedzīvotāju skaita pārdali no attālākiem Latvijas rajoniem par labu Rīgai un Pierīgai. Tā kā migrē galvenokārt 20-30 gadu veci, tātad visauglīgākā vecuma cilvēki, dzimstība izbraukšanas vietās mazinājās. Taču jaunajās apmešanās vietās tā nepalielinājās, jo dzīvokḷu celtniecība būtiski atpalika no migrācijas pieauguma, un dzīves telpas trūkuma dēl bērnu skaits tika ierobežots ne tikai iebraucēju, bet arī vietējo ğimenēs. Tas pats notika arī starprepubliku migrācijā. Latvijā visvairāk cilvēku iebrauca no tuvējiem Krievijas un Baltkrievijas apgabaliem - Pleskavas, Vitebskas, Kaḷiņingradas. Arī tajos saruka jaunāko vecumgrupu īpatsvars un tātad arī dzimstības līmenis, kā arī iespējas ilgstoši radīt lielu izceḷotāju skaitu.

Gribot negribot raisījās secinājums, ka jauno darbavietu izvietojums galvenokārt Rīgā un tās tuvumā (Jelgavā, Ogrē, Olainē) kavē pārējo pilsētu attīstību un pilnīgāku attālāko apvidu darbaspēka ataudzi un izmantošanu ne vien Latvijā, bet arī tai tuvējos izbraukšanas apgabalos. Šo apsvērumu dēḷ nebija lietderīga jaunu darbavietu veidošana rūpniecības uzṇēmumos, kas izmanto no citām republikām ievestās izejvielas un darbaspēku, bet produkciju izved uz tām. Tas pilnībā sakrita ar minēto nacionālekonomistu nostādni, kaut arī netiku ar to iepazīstināta.

Kā jau zinātnē, lietotās metodikas un izmantoto datu apraksts, kā arī iegūtie secinājumi bija jāizliek uz papīra. Tos izklāstīju īpašā 72 lpp. garā brošūrā ar 7 tabulām un 6 kartoshēmām (Эглите 1967). Tā kā tajā bija iekḷauti vien̄igi dienesta lietošanas izdevumos publicētie dati, arī šo darbiṇu izdeva 100 numurētos eksemplāros, pieticīgi drukātus rotaprinta tehnikā (1. attēls).

Jau pēc 1970. gada tautskaites ar pilnīgāku datu atklātu izdošanu (Латвийская CCP ...1971) sagatavoju publicēšanas nosacījumiem atbilstošu rakstu Latvijas Zinātṇu akadēmijas vēstīm par migrācijas ietekmi uz apmaiņas teritoriju iedz̄ivotāju vecumsastāvu un ataudzes iespējām (Eglīte 1972). Visās zinātniskajās iestādēs tolaik darbojās pāris kolēǵu ekspertīzes komisijas vērtējumam, vai rokrakstā nav publicēšanai liegtu datu. Tad to apsprieda institūta zinātniskā padome, un ar tās labvēlīgu atzinumu varēja iesniegt redakcijā. Pirms salikuma tekstu vēl pārbaudīja Galvenā literatūras pārvalde, kā dēvēja cenzūru. Mans raksts tai bija licies aizdomīgs (2. attēls). 


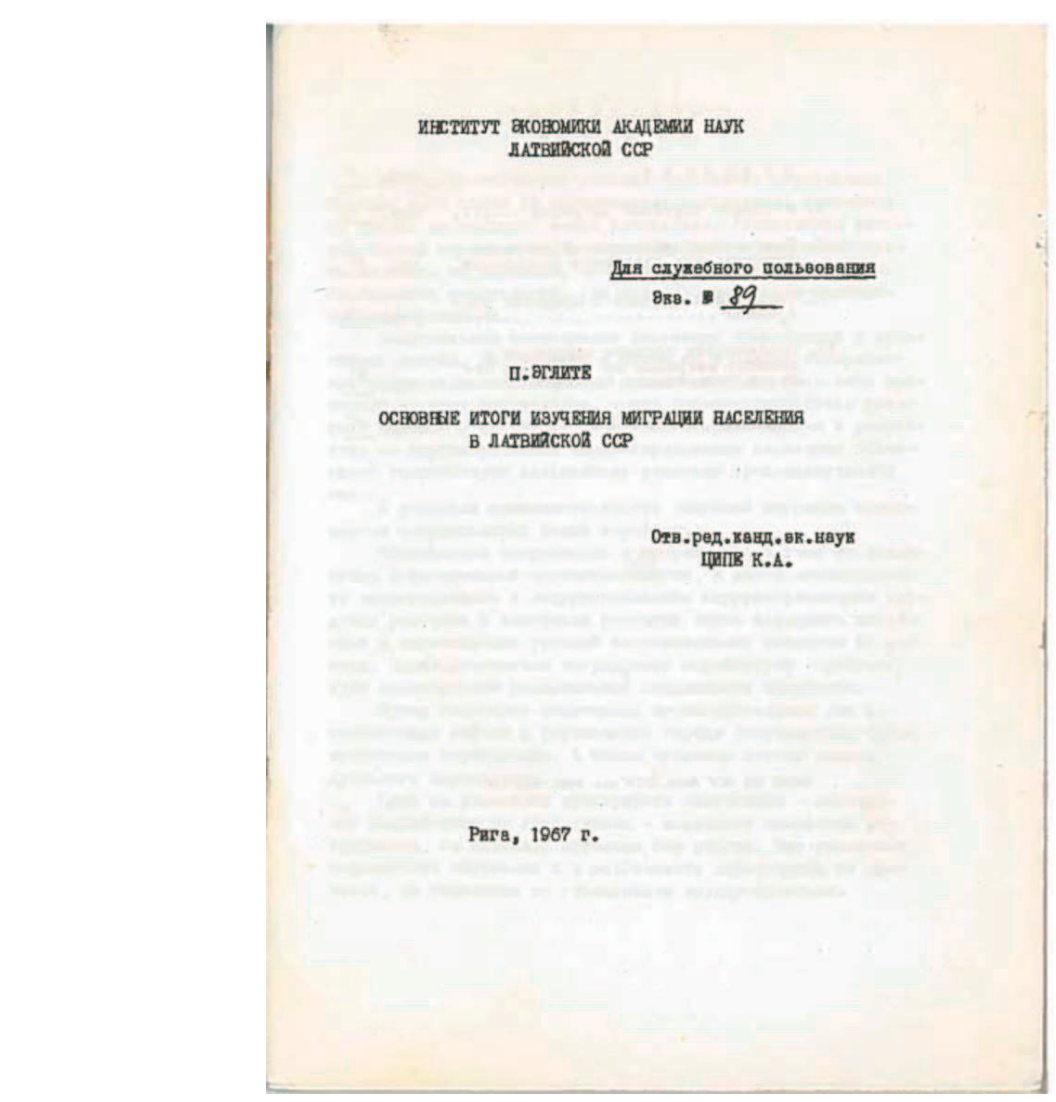

1. attēls. Pētījums par migrāciju "Dienesta lietošanas" vajadzībām

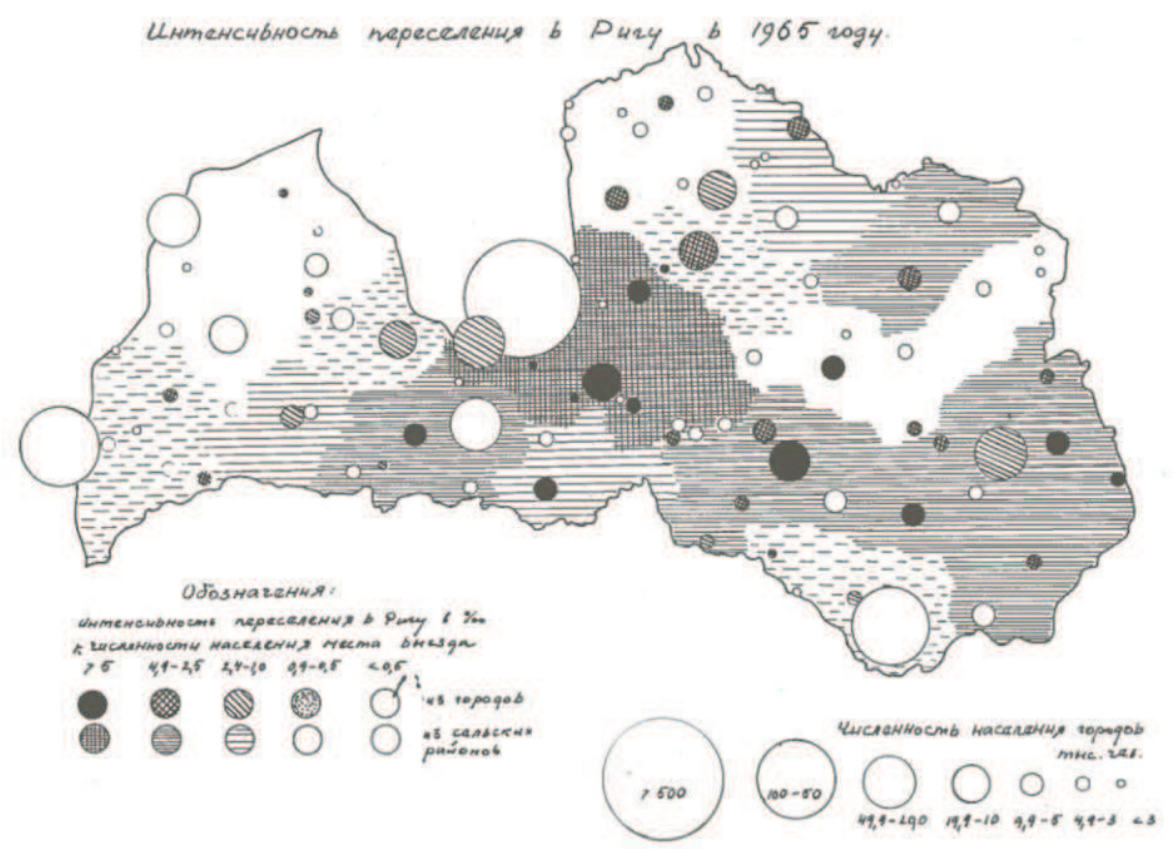

2. attēls. Migrācijas intensitāte uz Rīgu 1965. gadā (Эглите 1967)

Toreizējais institūta direktora vietnieks zinātniskā darbā Pēteris Guḷāns man darīja zināmu, ka par to ticis spriests Latvijas Kompartijas Centrālajā komitejā, un ieteica pameklēt, vai kas līdzịgs nav publicēts kāda cita padomju pētnieka darbā. Neatradu, jo nevienā citā republikā nebija tik liela migrācijas un tik maza dabiskā pieauguma. Tāpēc arī tajās bija mazākas notiekošās vecumsastāva novecošanās izpausmes un paredzamās 
sekas. Attaisnoties nespēju. Sekoja, pēc H. Stroda vārdiem, "politiskās represijas": turpmākajos 3 gados neviens Latvijas preses izdevums manus rakstus nelūdza un iepriekš iesniegtos neiespieda. Vēstures institūta kolēǵes, braucot Zinību biedrības lektoru grupā uz kādu no rajoniem, man pat apjautājās, vai neesmu pazemināta amatā. Nebiju. Un tad 1975. gadā “Cīṇā” pēkšņi parādījās mans jau agrāk iesniegtais raksts par brīvā laika izlietojumu. Tātad biju apžēlota (3. attēls).

Tikai pēc Latvijas neatkarības atgūšanas publicētajos iepriekš slepeno dokumentu kopijās atradu sava "prese lieguma" iemeslu. Toreizèjās "Glavlitia" (Galvenā literatūras pārvalde) vadītājas ikgadējā slepenajā atskaitē Latvijas Kompartijas "Cekai” (Centrālā komiteja); līdzās Latvijā visnotal cienījamu rakstnieku darbu kritikai mans darbs tika minēts kā izdošanai nevēlams. Tajā esot minēts, ka starprepubliku migrantu izglītības līmenis esot zemāks nekā vietējiem, un šādu apgalvojumu trimdas latvieši varētu izmantot pretpadomju aǵitācijai (PSRS politiskā ... 2011, 231).

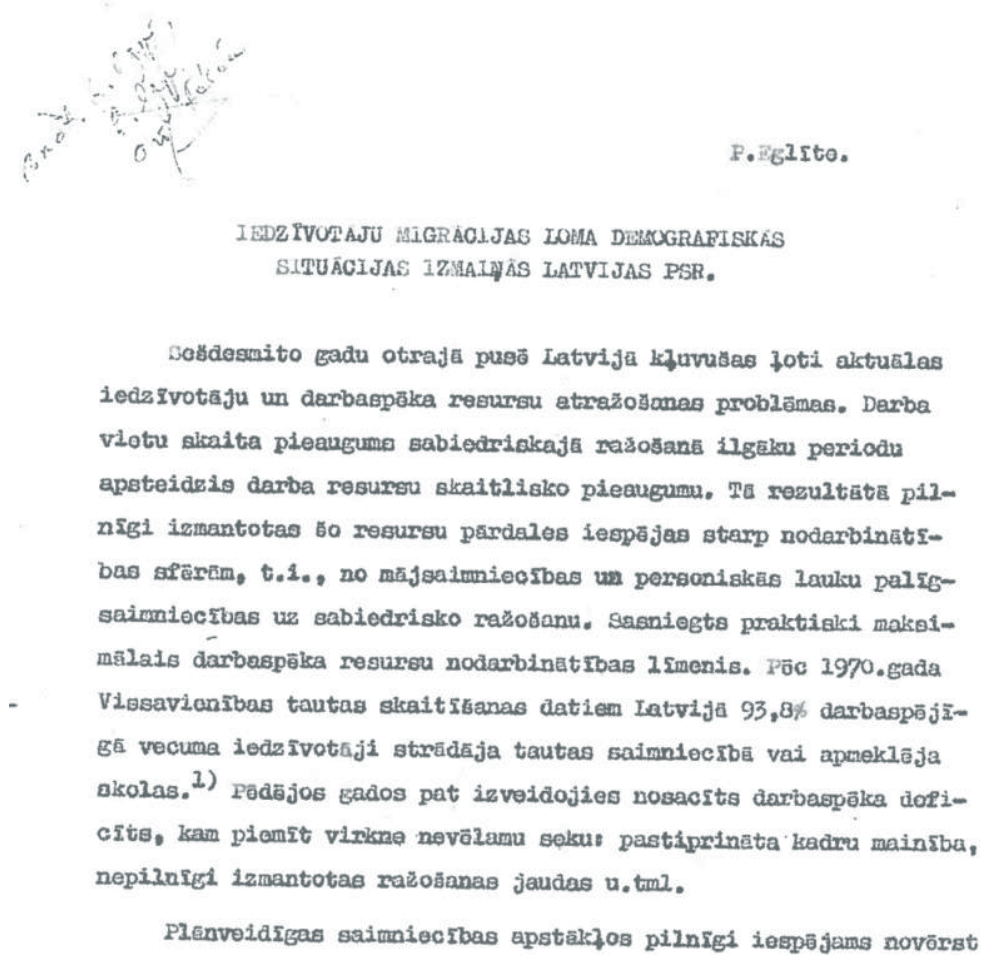

3. attēls. Publicēšanai nevēlamā rokraksta fragments ar cenzora piezīmēm

Man pašai šī grēka darba eksemplāra vairs nebija, jo autora kā parasti saglabātais bija mistiski pazudis no vāciniem darbavietas grāmatu skapī ... Atradu citu - pat ar kāda vērtētāja piezīmēm teksta malās - jau mūsdienās Misiṇa bibliotēkas retumos. Izrādījās, ka atmiņa mani nebija vīlusi: Glavḷita priekšnieces atskaitē minētās norādes par iebraucēju zemāko izglīīîu tur nebija ... Tātad: ja rokrakstā nebija iegansta aizliegt publicēšanu, tad tas bija jāizdomā, lai tikai atklāti neparādītos teksts, kur pievērš uzman̄̄bu nesamērīgajai imigrācijai ar visām tās sekām. Tādas tikai mūsdienās sāk izjust arī viena otra cita Eiropas Savienības valsts (Lutz, Scherbow 2003), un arī Latvijā nebūt ne visas jau pārvarētas. 


\section{Atsauces}

Eglīte, P. (1972). Iedz̄̄votāju migrācijas loma demogrāfiskās situācijas izmain̄ās Latvijas PSR. Rokraksts, 1-25. (Misiṇa bibliotēkas retumu krājumā)

Latvija padomju režìma varā 1945-1986 (2001). Dokumentu krājums. N 6. Šneidere, I. (red.) Rīga: Latvijas vēstures institūta apgāds.

Latvijas PSR tautas saimniecība (1957). Statistikas datu krājums. Rīga: LPSR CSP.

Lutz, W., Scherbow, S. (2003). Can immigration compensate for Europe's low Fertility? European Demographic Research Papers, 1, 1 - 16.

https://www.oeaw.ac.at/fileadmin/subsites/Institute/VID/PDF/Publications/EDRP/edrp_2003_01.p df (28.02. 2018)

Multilingual Demographic Dictionary (1982). Ordina editions, Liege (Belgium)

Okupācijas varu politika Latvijā 1939.-1991. (1999). Dokumentu krājums. Rīga: Nordik, 349 - 376.

PSRS politiskā cenzūra Latvijā 1940.-1990. (2011). Dokumenti un materiāli. 2. daḷa. Sast. H.Strods, Rīga: Jumava, 229- 238.

Естественное и механическое движение населения Латвийской ССР (1961). Рига, (ДСП) (для служебного пользования)

Итоги Всесоюзной переписи населения 1959 г. (1962). Латвийская ССР. Москва: ЦСУ.

Латвийская ССР в 1970 г. (1971). Краткий статистический сборник. Рига

Численность, состав, естественное и механическое движение населения Латвийской ССР в 1971 году (1972-1988) (1972 (1973-1989)). Рига. (ДСП)

Численность, состав и движение населения Латвийской ССР (1966). Рига (ДСП)

Эглите, П. (1967). Основные итоги изучения миграции в Латвийской ССР. Рига: Институт Экономики АН Латв.ССР (ДСП)

\section{Summary}

This article focuses on the peculiarities of migration and its research possibilities during the Soviet era, when Latvia experienced massive immigration mainly from regions of Russia and Belarus that were in close proximity. That led to distortion of population age composition both in the places of origin and in the new places of residence. As a result there was excessive aging, which occurred sooner in the places of origin, and later in the new places of residence. To constrain the effects of ongoing soviet policy, the availability of data was limited, but prepared publications were politically censored. 